\title{
Az egri egyházmegyei Oltáriszentség Társulatok 1783-as regulája*
}

A vallásos társulatok első virágkorának Magyarországon a késő középkor számított, amelyet azonban derékba tört a reformáció és a török hódoltság. ${ }^{1}$ A 18. század elejétől ismét százával alakultak különféle hitbuzgalmi társulatok hazánkban, amelyek a barokk vallásosság meghatározó elemeivé váltak. ${ }^{2}$ Az egyik legnépszerűbb társulatnak az Eucharisztia tiszteletéhez kapcsolódó ${ }^{3}$ Oltáriszentség Társulat (Confraternitas

* A tanulmány eredeti megjelenési helye: Az Oltáriszentség és az Úrvacsora a magyarországi vallási kultúrában. Szerkesztő: Barna Gábor. Szent István Társulat - Szent István Tudományos Akadémia, Bp. 2020.

1 Pásztor Lajos: A magyarság vallásos élete a Jagellók korában. Bp. 1940; Kubinyi András: Vallásos társulatok a késő középkori magyar városokban. Magyar Egyháztörténeti Vázlatok 9. évf. (1998) 1-2. sz. 123-134.; Marie-Madeleine de Cevins: Koldulórendi konfraternitások a középkori Magyarországon (1270 k. - 1530 k.). Pécs 2015.

2 A 18. századi vallásos társulatok átfogó összegzését lásd: Tüskés Gábor - Knapp Eva: Vallásos társulatok Magyarországon a 17-18. században. In: Néprajzi Látóhatár 1. (1992) 8-36., Juhász Miklós: Magyarországi konfraternitások a barokk korban. Katholikus Szemle 1944. június 161169. Néhány helyi társulat, illetve társulati típus története és jellemzői már feldolgozásra kerültek, például: Barokk vallásos közösségek. (Pázmány Irodalmi Mủhely - Lelkiségtörténeti tanulmányok 15.) Bp. 2017; Mohl Antal: A Mária-kongregácziók története. Különös tekintettel hazánkra. Győr 1898; Barna Gábor: A tállyai Fáklyás Társulat dokumentumai. (Devotio Hungarorum 3.) Szeged 1996; Tóth János: A barkai Skapuláré Társulat története. Szerk. Barna Gábor (Devotio Hungarorum 8.) Szeged 2002; Lénárt Andor: Vallásos konfraternitások Gyöngyösön a XVII-XVIII. században. In: Archivum 2. (1974) 33-46.; Lénárt Andor: A confraternitások mint szőlőmíves céhek. In: Archivum 4. (1975) 96-102.; Kádár Zsófia: Az urak Patrona Hungarie-társulata a 17. században. In: Jezsuita jelenlét Győrben a 17-18. században. Tanulmányok a 375 éves Szent Ignác-templom történetéhez. Szerk. Fazekas István - Kádár Zsófa - Kökényesi Zsolt. Győr 2017. 307-333.; Kádár Zsófia: Jezsuita vezetésű vallásos társulatok Magyarországon a 17. században (1582-1671). In: Századok 148. évf. (2014) 5. sz. 1229-1272.; Horváth József: Győri kongregációk a 18. század közepén. In: Népi vallásosság a Kárpát-medencében III. Pécs 2000. 160-170.; Szelestei Nagy László: Jézus Szíve Társulatok a Kárpát-medencében a 18. században. In: Magyar Sion 6. évf. (2013) 2. sz. 195-204.; Szelestei Nagy lászló: A győri Magyarok Nagyasszonya Társulat a 17. században. In: $\mathrm{Az}$ áhítat nem hivatalos alkalmai és formái az 1800 előtti Magyarországon. (Pázmány Irodalmi Mủhely - Lelkiségtörténeti tanulmányok 4.) Piliscsaba 2013. 203-218; Farmati Anna: Mennyröl szállott Jerusalem. A kolozsvári Szentháromság társulat mint mennyország. In: Menny és pokol a barokk kori ember életében. (Pázmány Irodalmi Mühely - Lelkiségtörténeti tanulmányok 7.) Bp. 2014. 111-120.

3 Söveges Dávid: Fejezetek a lelkiség történetéből. Pannonhalma 2007. I. 192.; Szántó Konrád: A Katolikus Egyház története. Bp. 1983-1987. I. 545., 562. 
Corporis Christi) számított. ${ }^{4} \mathrm{~A}$ római anyatársulatot (Archiconfraternitas Corporis Christi) 1606-ban alapította V. Pál pápa (1605-1621) az Eucharisztia lehető legnagyobb és állandó tiszteletére, melyet másfél száz évvel később, 1747-ben XIV. Benedek pápa (1740-1758) újabb rendkívül gazdag búcsúkiváltságokkal látott el. ${ }^{5}$

Az Egri Egyházmegyében a társulatot Barkóczy Ferenc püspök (1744-1761) honosította meg. 1757. november 5-én az egri „Öreg Templomban”, vagyis az akkori székesegyházban ünnepélyes keretek között megalapította az Oltáriszentség Főtársulatot, melynek tagjai közé beiratkozott nemcsak a város sok egyházi és világi neves személyisége, hanem még Mária Terézia királynő és családja is, melyet saját kezủ aláirásaik bizonyítanak a társulat gyönyörüen illusztrált albumában, mely az egri Főegyházmegyei Könyvtár egyik legnagyobb becsben tartott kötete. ${ }^{6}$

Bár Barkóczy püspököt hamarosan esztergomi érseknek nevezték ki, és így elkerült Egerből, de utódja, Eszterházy Károly püspök (1761-1799) hasonló lelkesedéssel folytatta elődje munkáját, immár az egész egyházmegyében elterjesztve a társulatot. ${ }^{7}$ A 18. század második felében az Egri Egyházmegyében kimutatható mintegy 240 vallásos társulat ${ }^{8}$ döntő többsége Oltáriszentség Társulat volt, a jóval kisebb számban jelenlévő Szentháromság Társulat, Szent Kereszt Társulat, Agonia Christi Társulat, Szűz Mária-társulatok (Mária szeplőtelen fogantatása, Mária tisztulása, Mária mennybevétele, Mária neve, Mária látogatása), Rózsafüzér Társulat, Szent Anna Társulat és ferences harmadrend mellett. A feloszlatás előtt, 1785 körül összesen 14 esperesi kerületben több mint ötven Oltáriszentség Társulat működött az egyházmegyében, amely hozzávetőlegesen nyolc-tízezer tagot jelenthetett. ${ }^{9}$

A társulat első reguláját Barkóczy Ferenc püspök még az egyházmegyei főtársulat megalapítása előtt egy évvel, 1756-ban adta ki, jó „marketingfogással” előre kedvet

4 Söveges D.: Fejezetek i. m. II. 103.; Szántó K.: A Katolikus Egyház i. m. II. 239., 307.; A magyarországi barokk Oltáriszentség Társulatok általános ismertetését lásd: Szelestei Nagy László: A magyarországi barokk kori Oltáriszentség-társulatokról. In: Barokk vallásos közösségek. (Pázmány Irodalmi Műhely - Lelkiségtörténeti tanulmányok 15.) Bp. 2017. 189-198.

5 Az Oltári Szentség Fő-Társaságának Regulái. Bútsúk és Malasztok, mellyeket A Római Szentséges Pápák abban lévő Kristus Híveinek bővségesen ki-osztogattak. Eger 1783. 2-14.

6 Löffler Erzsébet: Az Egri Főegyházmegyei Könyvtár Barkóczy Albuma. Acta Academiae Agriensis, Sectio Historiae 37 (2010) 83-103.; Böhm János: Gr. Barkóczy Ferencz egri püspök megalapítja 1757-ben az Oltáriszentség fótársaságát. Egri Egyházmegyei Közlöny 29. (1897) 22., 32-35.; Sugár István: Az egri püspökök története. Bp. 1984. 409.

7 Kovács Béla: Az egyházmegye plébániái és fíliái Eszterházy Károly püspöksége idején. In: Eszterházy Károly Emlékkönyv. Szerk. Kovács Béla. Eger 1999. 85.; Mihalik Béla Vilmos: Plébános és közösség a 18. század közepi egri egyházmegyében. In: Alsópapság, lokális társadalom és népi kultúra a 18-20. századi Magyarországon. Szerk. Bárth Dániel. Bp. 2013. 96-98.

8 Tüskés G. - Knapp É.: Vallásos társulatok i. m. 14.

9 Egri Főegyházmegyei Levéltár Archivum Vetus 3199. Tabellae Congregationum. 


\section{A Z \\ OLTÁRI SZENTSÉG FÓ.TÁRSASAGÁNAK \\ R E G U L Á I \\ BÚTSÚK, és MALASZTOK, MELLYEKET \\ A' Római Szentséges Pápák abban lévo̊ Kriltus Hiveinek bơvségefen ki-ofztogattak.}

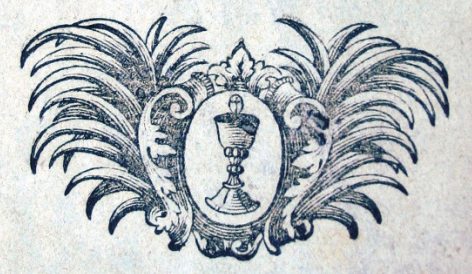

E G E R B E N,

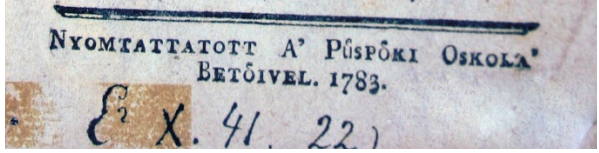

\section{1. kép: Az Oltáriszentség Fötársulat szabálykönyve}

csinálva a híveknek a belépéshez. ${ }^{10} \mathrm{Az}$ elkövetkező harminc évben Eszterházy Károly püspök buzgólkodása nyomán a társulat olyannyira elterjedt az egész egyházmegyében, hogy újból szülkségessé vált a regula kiadása, ${ }^{11}$ melyre utolsó alkalommal - nyilván nem számítva a két év múlva bekövetkező feloszlatásra - 1783-ban került sor magyar és német nyelven. ${ }^{12}$ A kötet felépítése megfelel a többi korabeli társulati regulában szokásos tartalmi és formai jellemzőknek. ${ }^{13}$

A szabályzatból megismerhetjük az Oltáriszentség Társulat szabályait és működését, csakúgy, mint a tagokkal szemben támasztott elvárásokat, melyek sok hasonlóságot mutatnak más barokk kori társulatok müködésével. ${ }^{14}$ A társulati tagságot nem kötötték különösebb feltételhez, minden férfi és nő szabadon beléphetett, nyilván csak a megfelelő erkölcs lehetett kitétel.

10 Minden társaságok annyának, az az az egri püspökségben fel-állíttatott Oltári Szentség Főtársaságának könyvetskéje, melyben foglaltatnak a’ butsuk, regulák és a’ mindennapi ajtatosságoknak gyakorlásira alkalmaztatott imádságok és énekek. Eger 1756. A közelmúltban megjelent nyomdatörténeti bibliográfiában lásd: Mizera Tamás - Nagy Andor - Verók Attila: A könyvkiadó egri Líceum. Történet és kiadványjegyzék I. (1755-1852). (Kulturális Örökség 7.) Budapest-Eger 2017. 76. Nr. 12. E munka elkészült német nyelven is, amelyet egy évvel később adtak ki Egerben. Lásd: Mizera T. Nagy A. - Verók A.: A könyvkiadó i. m. 78. Nr. 22. A jelenlegi kutatások 1642-ből ismerik az első hazai Oltáriszentség társulati regulás könyvet, melyet a soproni társulat számára adtak ki. Szelestei Nagy László: A magyarországi barokk kori i. m. 189-198.

11 Minden társaságok annyának, az az egri püspökségben fel-állíttatott Oltári Szentség fő társaságának könyvetskéje, mellyben foglaltatnak a bútsúk, regulák és a mindennapi ájtatosságoknak gyakorlásira alkalmaztatott imádságok, és énekek. Eger 1769., Mizera T. - Nagy A. - Verók A.: A könyvkiadó i. m. 143. Nr. 281.

12 Az Oltári Szentség Fő-Társaságának Regulái i. m.; Mizera T. - Nagy A. - Verók A.: A könyvkiadó i. m. 231. Nr. 643.; Erbauliche Andachts-Übungen sammt Ablaß, und Satzungen einer hochlöblichen Ertz-Bruderschafft des Allerheiligsten Altar-Sacraments in dem Ober-Ungarischen Bisthum Erlau. Erlau 1783., Mizera T. - Nagy A. - Verók A.: A könyvkiadó i. m. 228. Nr. 629.

13 Bán Izabella: A 18. századi katolikus társulatok regulái. In: Barokk vallásos közösségek. (Pázmány Irodalmi Mühely - Lelkiségtörténeti tanulmányok 15.) Bp. 2017. 19-30.

14 Bán I.: A 18. századi i. m. 19-30. 
Az új tagokat a helyi plébános vette fel a havonta megtartott társulati mise keretében a Credónál. Elöírás volt, hogy a tagok listáját külön társulati könyvben kellett vezetni, melybe a nevek mellé a társulatoknál szokásos módon beírták a beiratkozás és az elhalálozást dátumát is. ${ }^{15}$

A társulat egyházmegyei szintű hierarchiába szerveződött, mely élén protectorként, azaz fővédnökként maga Eszterházy Károly püspök állt. A társulat ügyeit legfelsőbb szinten az ún. Directori Tanács intézte, amely a directorból - aki rendszerint valamelyik egri kanonok volt, akit a püspök nevezett ki -, illetve két mellérendelt papi személyből állt. Esperesi kerületi szinten a helyi társulatok élén az ún. consultorok álltak, akik vagy az esperesek, vagy pedig a tapasztalt és buzgó plébánosok közül kerültek ki. Az ő feladatuk a kerületükbe tartozó társulatok működésének ellenőrzése, illetve az esetleges szabálytalanságok kivizsgálása volt, amelyekről évente kétszer - Szent György (április 24.) és Szent Mihály (szeptember 29.) napja táján - jelentést kellett tenniük a directornak. ${ }^{16}$

Az egyes helyi társulatok vezetői a prézesek voltak, amely tisztet a plébánosok töltötték be. A prézes elsősorban a társulat szabályszerű működésére felügyelt, amelyről negyedévente jelentést kellett tennie a consultornak. A tényleges szervező- és vezetőmunkát azonban a világi elöljáró, a prefektus végezte, akit minden év végén a prézes és a társulat „elei” választottak meg a tagságból egy jó erkölcsű férfi személyében. Ez minden bizonnyal komoly megtiszteltetésnek számított, ezért a prefektusok valószínűleg a falu elitjéből kerültek ki, erre utal, hogy például a csernelyi társulatot 1769 -ben Bíró István községi bíró vezette. ${ }^{17} \mathrm{~A}$ prefektusok feladata volt, hogy a társulati ájtatosságokat és szolgálatokat megszervezzék, azok rendes lefolyását biztosítsák, az egyes feladatokra a tagokat beosszák, a társulat ügyeit - például egy tag temetésének időpontját - a többiek tudomására hozzák, illetve hogy egyes tagok nem megfelelő viselkedését és a szabályszegéseket a prézesnek jelentsék. A prefektus kezelte a társulat pénzügyeit is. A prefektus sokrétű munkáját két férfi asszisztens segítette, akiket a prefektussal együtt választottak. Az asszonyok számára külön választottak egy-két prefektát a női tagok közül, akik

15 Az Oltári Szentség Fő-Társaságának Regulái i. m. 20., 37-43.; Néhány ilyen társulati könyv a mai napig fennmaradt, például az egyházmegyei fötársulat reprezentatív alapítási kötete, az egri Főegyházmegyei Könyvtárban található gyönyörüen illusztrált ún. Barkóczy Album. Szintén a Főegyházmegyei Könyvtárban található a jászárokszállási társulat 1778-as könyve - melyet majd száz év kihagyás után 1876-tól másodlagos felhasználásként újabb hitbuzgalmi társulatok, az Oltáregylet és a Rózsafüzér Társulat névkönyveként hasznosítottak - és az egerszalóki társulat névkönyve is (MS 2074). Az Egri Szemináriumi Könyvtár őrzi a Püspöki Iskolában 1764-ben alapított anyatársulat névkönyvét.

16 Az Oltári Szentség Fő-Társaságának Regulái i. m. 15-18.

17 Eszterházy Károly püspök egyházlátogatásainak jegyzőkönyvei. Borsod vármegye 1768-1769. Szerk. Kovács Béla. Eger 1998. 179. 
a társulat elsősorban női feladatkörökhöz kapcsolódó ügyeit intézték - valószínüleg a lobogók hímzését, a betegek gondozását és hasonlókat -, de a prefektusok felügyelete alatt. ${ }^{18}$

Egyes plébániai társulatok fióktársulatokkal is rendelkeztek a filiákban - például a csernelyi anyatársulatnak három fióktársulata is müködött Darócon, Csokván és Ományban -, amelyeket saját helyi elöljáróik irányítottak, de az anyatársulat prefektusának vezetése alatt. ${ }^{19}$

A társulati élet gerincét - hasonlóan a többi korabeli hitbuzgalmi társulathoz - a rendszeres havi vallásos összejövetelek jelentették. Minden újhold vasárnapján a plébániatemplomban énekes társulati misét mondattak szentségkitétellel és körmenettel, majd este litániát tartottak az Eucharisztiáról, melyeken valószínúleg a filiákban működő fióktársulatok tagsága is részt vett. ${ }^{20}$

A társulat fó céljának, az Eucharisztia lehető legnagyobb tiszteletének egyik megnyilvánulási formája az Oltáriszentség ünnepének, az úrnapjának ${ }^{21}$ a korban szokásos ékes külsőségekkel való megünneplése volt, melyet a Trienti Zsinat is elöírt. ${ }^{22} \mathrm{~A}$ fényes úrnapi - vagy a filiákban az ún. kisúrnapi, vagyis a rákövetkező vasárnap tartott ${ }^{23}$ - körmeneten a társulat tagjai közül hat férfi égő fáklyával vette körül az Eucharisztiát, míg a többi férfi a társulat zászlaja alatt párosával vonult a pap előtt égő gyertyákkal, a nők pedig közvetlenül a pap után ugyanígy kísérték a Szentséget, mivel az eucharisztikus társulatok kiváltsága volt, hogy a vallásos egyesületek közül ők vonulhattak a körmeneteken a legközelebb az Oltáriszentséghez. ${ }^{24} \mathrm{Az}$ úrnapja nyolcadában is minden nap ünnepélyes szentségimádást tartott a társulat tagsága a mise és a vecsernye alatt a templomban, ahol az adott időpontra beosztott kettő vagy négy tag egy „arra rendeltetett ruhában”, vagyis társulati egyenruhában térden állva imádkozott az Eucharisztia előtt. A szentségimádáson lehetőség szerint mindenkinek részt kellett vennie. ${ }^{25}$

18 Az Oltári Szentség Fő-Társaságának Regulái i. m. 19-20.

19 Eszterházy Károly püspök egyházlátogatásainak jegyzőkönyvei i. m. 179.

20 Az Oltári Szentség Fö-Társaságának Regulái i. m. 25.

21 Az úrnapja az Oltáriszentség külön ünnepe, mely a II. Vatikáni Zsinat elött a Szentháromság vasárnapját követő csütörtökre eső parancsolt ünnep volt, ma már a rákövetkező vasárnap tartják.

22 Szántó K.: A Katolikus Egyház története i. m. II. 174., 307.; Söveges D.: Fejezetek i. m. II. 103.

23 Általában úrnapján csak a plébániákon tartottak körmenetet, illetve ha egy településen több templom is volt, akkor is csak egy körmenetet tartottak a legmagasabb rangú templomból (ecclesia dignior) kiindulva, míg a filiákban, illetve a többi templomban a következő vasárnap, az ún. kisúrnapján tartották meg a processziót. Mihályfi Ákos: A nyilvános istentisztelet. Bp. 1923. 161-162., 628630.; Sipos István: Az uj egyházi törvénykönyv főbb vonásai és utasításai. 1918. 166-167.

24 Sipos István: Katholikus egyházjog. Pécs 1928. 115.

25 Az Oltári Szentség Fő-Társaságának Regulái i. m. 21-22., 33. 
A társulatok bekapcsolódtak a korban népszerủ más eucharisztikus ájtatosságokba is. Jézus Krisztus háromnapos sírban nyugvása emlékezetére ún. negyvenórás szentségimádást szerveztek, mely a 16. századtól népszerű ájtatossági formának számított az egyházban. ${ }^{26}$ Pünkösd első, második és harmadik napján reggel hattól délig, majd egy órától este hatig ünnepélyes formaságok között - „minden ki-telhető tisztességgel” - folyamatos szentségimádást tartottak, a keresztény fejedelmek közötti békesség, az eretnekségek kiirtása, a katolikus egyház felmagasztalása és Magyarország számára az isteni irgalmasság kiesdése céljából. Ennek keretében a legalább hat égő gyertya közé kihelyezett Eucharisztia előtt a prefektus által kijelölt kettő vagy négy társulati tag - akiket óránként váltottak - a fentebb említett, kimondottan a szentségimádás ünnepélyesebbé tételét szolgáló társulati ruhában térden állva imádkozott. A regulák előírták a többi tag számára is, hogy amikor csak tudnak, vegyenek részt az ájtatosságon. A szentségimádás végén, a harmadik este gyertyás és fáklyás szentségi körmenetet tartottak. ${ }^{27}$

A társulat tagjai részt vettek az itáliai eredetű örökimádási mozgalomban is, ${ }^{28}$ mely párhuzamba vonható a korabeli Szentháromság Társulatok hasonló imádási módjával. ${ }^{29}$ Egyházmegyei szinten felosztották az év minden óráját a társulati tagok között, akik a plébánosuknál kihúztak egy cédulát, amelyen az imádás órája szerepelt. Ezt magánimával kellett tölteniük az Oltáriszentség tiszteletére és az esetleg éppen akkor haldokló tagtársaik megsegítésére, lehetőleg gyónás és áldozás után. Ha valaki nem tudott olvasni, akkor a rózsafüzér imádkozását ajánlották a regulák, ha tudott, elsősorban az Eucharisztiáról szóló litániát javasolták, amit a társulati reguláskönyvben is közöltek. ${ }^{30} \mathrm{Ha}$ valaki meghalt, a céduláját azonnal vissza kellett adni, hogy egy másik tag megkaphassa, és ne szakadjon meg az állandó imádás láncolata. ${ }^{31}$

A betegekhez a Szentség méltó, ünnepélyes kísérete szintén a társulat fö kötelességei közé tartozott, mely - különösen vegyes vallású vidékeken - a katolicizmus propagálásának fontos eszköze volt, és így ellenreformációs színezettel is bírt. Ha beteghez kérték a Szentséget, és ennek jelzéseként megcsendítették a harangot, akkor a prefektus által minden héten kijelölt két tagnak azonnal a templomba kellett sietnie és onnan elkísérnie a papot az ún. umbellát vagy supellátot, azaz díszes hordozható baldachint tartva a Szentség fölött, mellyel minden egyes társulatnak

26 Mihályfi Á.: A nyilvános i. m. 655-658.; Szántó K.: A Katolikus Egyház története i. m. II. 174.

27 Az Oltári Szentség Fő-Társaságának Regulái i. m. 22-25., 33.

28 1592-tól Rómában a város templomaiban felváltva folymatosan ki volt téve az Eucharisztia imádásra. A szokás a 18. századra elterjedt más vidékeken is. Szántó K.: A Katolikus Egyház története i. m. II. 174.

29 Bán I.: A 18. századi i. m. 22.

30 Az Oltári Szentség Fő-Társaságának Regulái i. m. 43-47.

31 Az Oltári Szentség Fő-Társaságának Regulái i. m. 34-37. 
rendelkeznie kellett. Másik két tagnak vagy - ha valószínűleg nagy munkálatok idején nem jelentek meg - két gyereknek az volt a dolga, hogy égő lámpást vigyen előtte. A társulat többi tagjának is ajánlották az Eucharisztia elkísérését, s míg a pap bent volt a betegnél, az udvaron kellett csendben imádkozniuk. Ha erre nem volt módjuk, a harang csendítését hallva legalább otthon kellett elmondaniuk leborulva egy Miatyánkot és egy Üdvözlégy Máriát a betegért. ${ }^{32}$

A tagok kötelessége - vagy még inkább kiváltsága - volt a szent sír őrzése is nagypénteken. Ennek oka feltehetően az a 16. századi német eredetű eucharisztikus szokás lehetett, hogy a szent sírra fátyollal letakarva kihelyezték a monstranciát. ${ }^{33} \mathrm{Ha}$ egy településen több templom is volt - vagyis több szent sír -, ott ajánlott volt a plébániatemplomból kiindulva a plébános vezetésével a társulat zászlaja alatt körmenetben végiglátogatni sorra mind, miközben a fájdalmas rózsafüzér imádkozták. ${ }^{34}$

A tagok egyéb kötelezettségeit jelentette továbbá a gyakori gyónás és áldozás, lehetőleg minden hónapban az újhold vasárnapi társulati miséhez kapcsolódóan és nagycsütörtökön, az Oltáriszentség alapításának emlékezetére. ${ }^{35} \mathrm{~A}$ korban ez viszonylag gyakorinak számított ${ }^{36}$ - még több mint száz év múlva terjed majd el X. Pius pápa hatására a gyakori, akár napi áldozás szokása ${ }^{37}$-, így a társulati tagok ezzel kiemelkedtek saját vallási közösségükből. Emellett jó példával kellett elöljárniuk a keresztény szeretet gyakorlásában is: segíteniük kellett a szükölködőket, látogatni a betegeket, kibékíteni a haragosokat és igyekezniük kellett lehetőségük szerint mindenhol jót tenni. ${ }^{38}$

A regulák a vallási elöírások mellett nagy hangsúlyt helyeztek a társulat mint közösség megfelelő mủködésére is. Ennek érdekében a tagok között erős, szinte testvéri kapcsolatot kívántak létrehozni, amely kiterjedt nemcsak az élő, hanem a megholt tagokra is. Ennek legalapvetőbb követelménye az volt, hogy a tagoknak egymás iránt nemcsak jóakarattal, hanem igaz keresztény szeretettel kellett viseltetniük.

A társulati összetartozás legjellemzőbb megnyilvánulása a beteg tagtársak ellátása volt. E célból évente, vagy ha ezt túl súlyos tehernek érezték, negyedévente kijelöltek négy, legalább negyvenéves tagot - két férfit és két nőt -, akik feladata a beteg tagok látogatása és lelki gondozása volt. Kötelességük volt a betegeket a szentségek vételére

32 Az Oltári Szentség Fő-Társaságának Regulái i. m. 27-28.

33 Magyar Katolikus Lexikon. Szent Sír. http://lexikon.katolikus.hu/S/szents\%C3\%ADr.html (2018. 06. 05.).

34 Az Oltári Szentség Fö-Társaságának Regulái i. m. 26.

35 Az Oltári Szentség Fő-Társaságának Regulái i. m. 26-27.

36 Szántó K.: A Katolikus Egyház története i. m. II. 173-174., 241.

37 Szántó K.: A Katolikus Egyház története i. m. II. 455., 470.

38 Az Oltári Szentség Fő-Társaságának Regulái i. m. 32. 
buzdítani, velük imádkozni, és ha szükségesnek látták, papot hívni. A beteg tagok halálküzdelmükben sem maradtak magukra, hanem számíthattak tagtársaik imáira, mivel a fentebb említett állandó szentségimádás egyik célja az abban az órában haldokló tagok lelki megsegítése volt. A betegek testi szükségleteire is oda kellett figyelniük: ha a beteg családjának nem volt pénze élelemre vagy temetésre, szólniuk kellett a prefektusnak, aki erre pénzt utalványozhatott ki a társulati kasszából. ${ }^{39}$ Ha valamelyik tag elhunyt, a tagok a társulati lobogó alatt testületileg vettek részt a temetésen, de aki nem tudott elmenni, az is imádkozott a megholtért otthon. ${ }^{40} \mathrm{~A}$ kor ízlésének és elvárásainak megfelelően egyes társulatok rendelkeztek a tagok temetését különlegesebbé és díszesebbé tevő eszközökkel is, például temetési feszülettel és fából készült koponyával és könyvvel, ${ }^{41}$ mely utóbbi valószínűleg a bibliai Élet könyvét szimbolizálta, melybe a Jelenések könyve szerint az üdvözült lelkek nevei kerülnek. ${ }^{42}$

A társulati lelki gondoskodás „eszköze” az élő és megholt tagokért évente mondatott négy-négy énekes mise volt. Az élőkért a kántorböjtök utáni első vasárnap, a purgatóriumban szenvedő lelkekért pedig a következő vasárnap utáni alkalmas hétköznapon mondattak misét a társulat vagyonából. ${ }^{43}$

A tagok a regulában előírt kötelességeik teljesítéséért cserébe a társulati imák és misék mellett részesültek a fötársulatnak adományozott gazdag búcsúkiváltságokban is, vagyis az ideig tartó evilági vagy purgatóriumi büntetés eltörlésében. A római anyatársulat eredeti, V. Pál pápa által adományozott búcsúkiváltságait XIV. Benedek pápa 1747-ben újabbakkal egészítette ki, amelyeket a megholt tagokra is kiterjesztett. Ennek értelmében a társulati tagok teljes búcsút nyerhettek a beiratkozásuk napján, ha előtte gyóntak és áldoztak; ha részt vettek az úrnapi vagy kisúrnapi körmeneten, és közben imádkoztak a keresztény fejedelmek egységéért, az eretnekségek kiirtásáért és a katolikus egyház felmagasztalásáért; illetve haláluk óráján, ha meggyóntak, áldoztak, és Jézust hívták segítségül legalább gondolatban. Emellett „kisebb szolgálat” fejében különféle részleges - például hét évi, száz napi stb. - búcsúkat is nyerhettek a tagok, például ha imádságos lélekkel beteghez kísérték az Oltáriszentséget, vagy részt vettek a társulat havi körmenetein, miséin vagy ájtatosságain. A regulák valójában nem sok kötelezettséggel terhelték a tagokat,

39 Az Oltári Szentség Fő-Társaságának Regulái i. m. 29-30.

40 Az Oltári Szentség Fő-Társaságának Regulái i. m. 30-31.

41 Egri Főegyházmegyei Levéltár Archivum Vetus 3199. Gyöngyöshalász 1784. Ezen felszerelések ritka esetben maradtak fenn, de más társulati „hagyatékokban” találkozhatunk velük, például egy ilyen célt szolgáló, rendkívül szép Purgatórium-ábrázolással díszített, fából készült társulati könyv található a Magyar Ferences Könyvtár és Levéltár gyűjteményben, mely a 18. században a bajai kordás társulaté volt.

42 Jelenések könyve 13,8; 21,27.

43 Az Oltári Szentség Fő-Társaságának Regulái i. m. 31-32. 
az elöírások a legtöbb esetben inkább csak erősen ajánlották az adott vallási cselekményben való részvételt - kivételt képeztek természetesen azok a feladatok, amelyek elvégzésére a prefektus beosztotta az egyes tagokat -, vagyis inkább arra szolgáltak, hogy lehetőséget teremtsenek a híveknek az egyes búcsúk elnyerésére. ${ }^{44}$

A társulatok némi - meglehetősen eltérő nagyságú - vagyonnal is rendelkeztek, melyek kezelését szintén részletesen szabályozták a regulák. Bevétellel rendelkezhettek a tagdíjakból, adományokból, hagyatékokból és kegyes alapítványokból, de egyes - fóleg Gyöngyös környéki - társulatok ennél jóval nagyobb vagyonnal - saját szőlővel, szántófölddel vagy réttel - is bírtak. A kiadásokat elsősorban a társulati misék stipendiumai jelentették, de emellett kötelességük volt az Eucharisztia méltó elhelyezését is elősegíteni oly módon, hogy az erre szolgáló különféle templomi felszerelésekről - elsősorban az örökmécsesbe való olajról és a gyertyákról -, illetve az oltárok díszítéséről gondoskodtak. A társulatok gyakran jótékonykodtak is, elsősorban a szegény tagok támogatásával. ${ }^{45}$

A társulatok jövedelmeit és kiadásait a prefektus kezelte, ezért a regulák ajánlották, hogy lehetőleg írástudó férfi töltse be ezt a tisztet, mivel könyvet kellett vezetni a bevételekről és a kiadásokról. A társulati vagyont rendkívül erős ellenőrzés alatt tartották, kizárva minden lehetséges visszaélést. A pénzt és a könyvelést egy kétkulcsos ládában kellett elhelyezni, amelynek egyik kulcsa a prefektusnál, másik a prézesnél volt. A prefektusnak csakis a prézes jóváhagyásával lehetett bármilyen kiadást eszközölnie, sőt nagyobb összeg esetén a consultor beleegyezésére is szükség volt. A prefektust minden évben elszámoltatta a plébános, a település bírája, két esküdtje és a társulat két-három tagja, majd a számadást elküldték a consultornak, ő pedig továbbította Egerbe a directornak, vagyis a legtávolabbi társulat anyagi ügyeit is ismerték és felügyelték az egyházmegyei központban. ${ }^{46}$

$\mathrm{Az}$ egyházmegye területén virágzó társulati életnek II. József feloszlatási rendelete vetett véget 1784-ben, amikor több más társulat után elrendelte az Oltáriszentség Társulatok működésének beszüntetését is. Bár Eszterházy püspök erőteljes tiltakozását fejezte ki, de a császár nem engedett, ezért a püspök 1785. október 20-i körlevelében kénytelen volt elrendelni, hogy a prézesek ne tartsanak többé társulati összejöveteleket, és ne vegyenek fel új tagokat. ${ }^{47}$ Ezzel a barokk Oltáriszentség Társulat végérvényesen megszűnt az egyházmegyében,

44 Az Oltári Szentség Fő-Társaságának Regulái i. m. 2-14.

45 Az Oltári Szentség Fő-Társaságának Regulái i. m. 20-21.; Egri Főegyházmegyei Levéltár Archivum Vetus 3199. Az egyes társulatok leltárai.

46 Az Oltári Szentség Fő-Társaságának Regulái i. m. 20-21.

47 Bőhm János: Az Oltáriszentség Fơtársaságának további sorsa az egri egyházmegyében. Egri Egyházmegyei Közlöny 29. (1897) 88. 
csakúgy, mint az ország egész területén. ${ }^{48} \mathrm{~A}$ 19. század második felében felvirágzó új eucharisztikus társulat, az Oltáregylet már egy teljesen új szerveződésnek számított, mely nem állt kapcsolatban a korábbi Oltáriszentség Társulattal.

48 A 18. századi vallásos társulatok megszűnése valószínűleg nem minden esetben volt ilyen gyors és egyértelmű. Egyes társulatokba - például a fentebb említett egerszalóki Oltáriszentség Társulatba - még a 19. század elején is vettek fel tagokat, de néhány társulat túlélte az elmúlt két évszázadot is, például a tállyai Fáklyás Társulat vagy a barkai Skapuláré Társulat (Barna G.: A tállyai Fáklyás Társulat i. m., Tóth J.: A barkai Skapuláré Társulat i. m.). A kérdés megválaszolása a jövőben még sok új kutatást igényel. 


\section{The rules of the Eger diocesan Confraternity of the Holy Eucharist from 1783}

Religious societies were among the most important factors of the Catholic religion in the previous centuries. The basic aims of the devotional societies was the cultivation of divine grace and special religious cults, for example the cult of the Eucharist. We can distinguish three periods in the history of these societies in the Eger Archdiocese: the Late Middle Ages and the Turkish era, the Baroque era, and the $19^{\text {th }}-20^{\text {th }}$ centuries. During the Baroque era, 242 societies were operating in the diocese. The most popular of them was the Confraternity of the Holy Eucharist. Bishop Ferenc Barkóczy published the first regulation of the Confraternity of the Holy Eucharist in Eger in 1756. Bishop Károly Eszterházy published the regulation once more in 1783. The regulation contained the duties and the privileges of the members therefore it reflects the life of the religious conrafternities in the Eger Dioecese in the Baroque era.

\section{Regula bratstiev Oltárnej sviatosti jágerského biskupstva z roku 1783}

Rozkvet náboženských bratstiev neskorého stredoveku bol v Uhorsku prerušený reformáciou a osmanskou nadvládou. Od začiatku 18. storočia sa na stovky zakladali opät rôzne formy bratstiev veriacich a sa stali sa určujúcim prvkom barokovej nábožnosti. Ich základným cielom bola Božia milost’ a starost́ o rôzne kulty, napr. o kult Eucharistie. Na území jágerského biskupstva evidujeme tri rôzne vývojové obdobia náboženských bratstiev: neskoro stredoveké a osmanské obdobie, barokové obdobie a obdobie 19.-20. storočia. Počas baroka tu pôsobilo 242 bratstiev. Jedno z najpopulárnejších z nich bolo Bratstvo Oltárnej sviatosti, presnejšie Kristovho tela (Confraternitas Corporis Christi). Na území biskupstva sa udomácnilo vd’aka biskupovi Františkovi Barkóczymu (1744-1761) a vdaka biskupovi Karolovi Eszterházymu (1761-1799) sa rozšírilo na jeho celom území. 